\title{
Sexually Transmitted Diseases: what adolescents know
}

\author{
Rosane Maria de Albuquerque ${ }^{1}$; Eloizy Victoria da Silva²; Maria Eduarda Bezerra de Souza e Silva ${ }^{3}$; \\ Maria Karollyne dos Santos Paiva ${ }^{4}$; Rayana Carla Silva de Morais ${ }^{5 *}$
}

1-3 Biomedicine student from the University Center of Vitória de Santo Antão (UNIVISA), Pernambuco-Brazil.

4 Pharmaceutical Sciences student from the University Center of Vitória de Santo Antão (UNIVISA), Pernambuco-Brazil

5 Advisor from the University Center of Vitória de Santo Antão (UNIVISA), Pernambuco-Brazil

E-mail adresses: rayanacarla@univisa.edu.br (Rayana Carla Silva de Morais)

${ }^{*}$ Corresponding author

\section{To cite this article:}

Albuquerque, R.M.; Silva, E.V.; Silva, M.E.B.S.; Paiva, M.K.S.; Morais, R.C.S. Sexually Transmitted Diseases: what do adolescents know. International Journal of Sciences. Vol. 1, No. 3, 2021, pp. 85-90. ISSN 2763-5392.

Received: 05 10, 2021; Accepted: 05 10, 2021; Published: 05 24, 2021

\begin{abstract}
Sexually transmitted infections (STIs) are a worldwide public health problem. The literature includes more than 30 sat-causing agents that can be classified as fungi, viruses and bacteria that can cause symptoms such as itching or even cause infertility or death. The objective of this study was to evaluate the level of knowledge of adolescents about sexually transmitted infections. A quantitative research was conducted through a questionnaire to assess the level of knowledge of adolescents from public schools in the city of Vitória de Santo Antão- PE (Brazil). Most adolescents knew the meaning of the acronym STIs $(80 \%), 74 \%$ said they knew of some sexually transmitted infection, $70 \%$ of the participants reported that the school did some kind of activity related to the prevention of STIs.
\end{abstract}

Keywords: Adolescents; Health education; Sexually transmitted infections.

\section{Introduction}

Sexually transmitted infections (STIs)are caused by fungi, bacteria and viruses, which are transmitted by sexual contact, without the use of female or male condoms, verticals transmission, syringe sharing or contact with contaminated blood. In the literature there are more than 30 agents that can cause these infections, being a worldwide public health problem. Some types of infections are curable, such as gonorrhea, while others are not, such as human immunodeficiency virus (HIV), which causes acquired immunodeficiency syndrome (AIDS) (BARBOSA et al 2019; BRAZIL, 2020; CRUZ et al, 2018; MUNIZ et al., 2020; SILVA, BARBOSA, 2018).

According to the World Health Organization (WHO) about 1 million people contract a curable STIs per day. According to the HIV/AIDS epidemiological bulletin of the Brazilian Ministry of Health, approximately 342,459 cases of HIV infection were reported from 2007 to June 2020 throughout Brazil. Where the male sex is highlighted as the predominant sex of cases, still presenting an increase in cases in the age group from 15 to 19 years. In those over 13 years of age, males with $51.6 \%$ of those infected stands out, with exposure due to homosexual or bisexual exposure, (BRASIL,
2020; WORLD HEALTH ORGANIZATION, 2016).

Syphilis, which has as an etiological agent a bacterium called Treponema pallidum, and stands out with an increase in transmission in all age groups. From 2010 to June 2020, 783 were detected. 544 cases of syphilis acquired in Brazil. There are reports of syphilis since the fifteenth century, being a systemic disease, which is almost silent, but has as one of the first signs a wound in the area where the entry of the bacterium occurred, usually in the genital area that disappears in a few days, also causes body stains even death for having degrees of severity, and may reach visceral organs, this STI is curable if treated at the beginning of symptoms (AVELLEIRA and BOTTINO, 2006; BRAZIL,2010; BRAZIL, 2020).

According to the WHO, about 357 million cases of curable STIs are diagnosed annually in people aged 15 to 49 years. Trichomoniasis, gonorrhea and chlamydia are curable STIs. Among the clinical signs, they cause genital lesions and urethral and vaginal discharge, in addition to causing pelvic inflammatory disease and can even cause infertility (WORLD HEALTH ORGANIZATION, 2016).

The school is an environment of importance for children and adolescents, it is a place where the first experiences in the social sphere take place. Thus, the school should not be used only as a basic education environment, 
but where this adolescent and child can have a lifelong learning. Among the various issues that should be addressed in schools, health education stands out. This approach is based on simple measures that provide an improvement in quality of life with the change of daily habits. Sexually transmitted infections are a risk for the entire population, especially for those vulnerable to information, knowing how to prevent and how to recognize symptoms is important information that every person should know. In view of the above, the objective of this study was to evaluate through a quantitative questionnaire the level of knowledge about STIs of elementary school students from Pernambuco, Brazil (ATALIBA; MOURÃO,2018, RAMOS; ARAUJO,2020, SILVA; FERREIRA, 2014).

\section{Methodology}

This is a cross-sectional, descriptive study using a quantitative approach. Held in state schools in the municipality of Vitória de Santo Antão-Pernambuco, Brazil. A total of 86 adolescents who were attending high school participated in this study in 2019 and 2020. The project was approved by the ethics committee, registered under the number CAAE: 17785319.3.0000.9227. Those responsible for the underage participants signed a free and informed consent form.

Data were collected through questionnaires specifically constructed to measure the degree of previous knowledge of these adolescents. The data extracted from the questionnaires were stored for analysis on the Microsoft Excel platform. After data analysis of the questionnaires, an explanatory lecture was held to elucidate the main doubts or lack of knowledge of the students about the STIs. To explain the subjects, didactic games, group dynamics and distribution of pamphlets and explanation with informative posters were used.

\section{Results and Discussion}

The study was conducted with the participation of 86 young people and adolescents, $88 \%$ aged between 15 and 18 years and $12 \%$ over 18 years, who were attending high school. A total of $61 \%$ of the participants were female and $39 \%$ male. About $80 \%$ of the participants said they knew the meaning of the acronym IST, while only $13 \%$ said they did not know the acronym. In our study, $80 \%$ of the adolescents reported knowing some STIs, however in Sousa et al. (2017) only $46.42 \%$ said they knew of some STIs.

In the study by Cruz et al. (2018), adolescents demonstrated the need and interest of higher frequency of classes related to the theme of sexuality $(54.7 \%)$, in contrast, in our study, the majority $(70 \%)$ reports that the school does activities related to the prevention of STIs. Carvalho, Pinto and Santos (2018) conducted a study in public schools in the city of Caxias-MA, in which $87.7 \%$ of the adolescents who participated in the research know the STIs, and also demonstrated that $51.8 \%$ received information about STIs in school, which shows that the school plays a fundamental role in assisting adolescents in the perception of different subjects, including sex education. According to Ataliba and Mourão
(2018) the school is a place that serves as a space for the development of actions that cause reflection and participation. The school has the role of providing information that leads to the formation of intellectual and moral character, it is also a place where the social insertion of the child and later the adolescent occurs. The school is also related to knowledge of different ethnicities, religions and cultures (SILVA; FERREIRA, 2014).

According to the present study, it was possible to observe that among the sexually transmitted infections presented (Figure1-A), hpv (68\%), gonorrhea $(60 \%)$ and candidiasis $(50 \%)$, which are the best known among adolescents. HPV (Human Papilloma virus) has the vaccine for its prevention, which potentially reduces the burden of cervical disease and precursor lesions, being made available through the SUS (Unified Health System), exclusively for adolescents, but does not provide protection for other STIs, and therefore requires the use of condoms (BRASIL, 2014).

Figure 1. Questions of the research conducted with adolescents/young people from basic education in Pernambuco, Brazil.

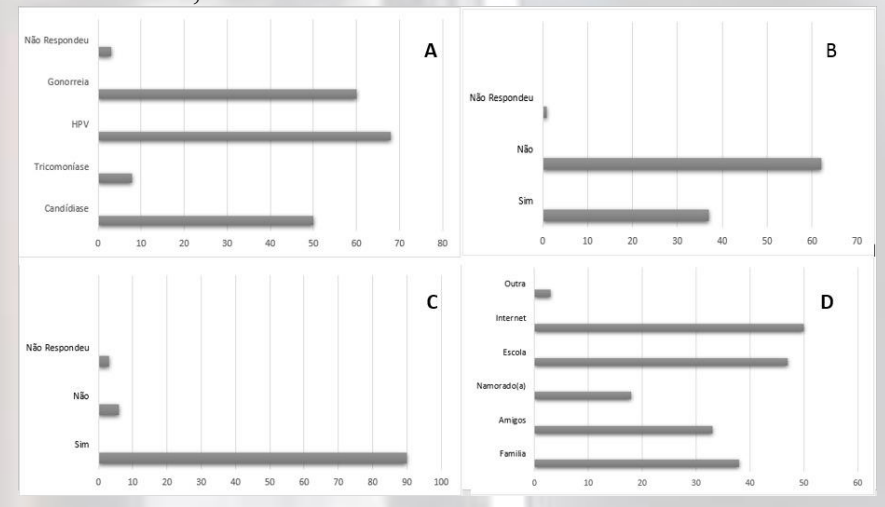

Legend: A- What sexually transmitted infection have you heard of? B- Do you know diagnostic tests for STIs? C - Is HIV/AIDS a type of STIs? DFrom what source do you inform yourself about sexuality?

Education for sexual health and reproductive health favors the development and knowledge of adolescents so that they can have positive and healthy attitudes in sexual life (BRASIL, 2018). As figure 1-B shows, most adolescents (62\%) they do not know the diagnostic tests for STIs, which demonstrates how important the intensification of attention and care for adolescent health in relation to sexual education and infections that can occur from sexual practices in an unprotected manner becomes.

As an example of infections that occur due to carelessness, such as not using preventive methods, one can speak of HIV, an infection that affects mostly young people and adolescents aged 15 to 24 years (BRASIL, 2006). Within the collected data (figure 1-C) it can be analyzed that most adolescents $(90 \%)$ has the understanding and knowledge that HIV is an STIs, but still a considerable number of about $6 \%$ do not recognize HIV being with STIs, making it important to consider self-care, health care, dialogue about STIs, their definitions and diagnoses, which will offer not only to adolescents, but to so many others the opportunity for educational reinforcement in prevention and treatment for 
those who come to discover some STIs (BRASIL, 2006).

In the present study, 50\% stated that they are informed about sexuality on the Internet, $47 \%$ report to school and $38 \%$ to family (Figure 1-D). Similar results were found in the work developed by Carvalho, Pinto and Santos (2018), in which $51.8 \%$ had the school as a source of information; also, in Sousa et al. (201 7) $46.79 \%$ of the participants stated that the source of information is in the school. According to Marola, Sanchez and Cardoso (2011), 40.7\% said that they seek information about sexuality on the Internet. This research on the Internet is due to the need to quench curiosities without the weight of judgment, leading the young person to sometimes consider incorrect information as true, which leads to increased transmission of STIs.

Regarding knowledge about contraceptives, $62 \%$ stated that these drugs do not protect against STIs. In the present study, $93 \%$ of the participating students reported knowing the male and female condoms. While $89 \%$ stated that the method of preventing STIs is through the use of condoms in all sexual intercourse. Similar results were found in Carvalho, Pinto and Santos (2018) where $91.8 \%$ also stated that condoms should be used in all sexual relations. The majority of participants, $66 \%$ said they had never participated in a school project on STIs and $93 \%$ showed interest in receiving more information about STIs through school activities. These data demonstrate that the school is a place of reception and multidisciplinary learning where not only curricular subjects should be addressed, but also issues that lead to social well-being and disease prevention.

\section{Conclusions}

The adolescents participating in the research have previous information related to sexuality and prevention of STIs, especially the majority who know the male and female condoms. It can also be highlighted that the greatest source of search for information on this theme is the Internet, this is a consequence of the advancement of the digital age, in which the world has faced a new pattern of relationship and social communication. Information taken from the internet may be wrong, as it can be written by people who do not have the competence to write about certain subjects. Another problem in seeking information on the Internet is fake news that can generate errors that compromise the physical integrity of this adolescent - In addition it is important to point out that $93 \%$ of participants said they were interested in receiving more information about STIs through school projects, which demonstrates the importance of health education in the school environment as a form of health promotion.

\section{Acknowledgements}

We thank UNIVISA for providing this study with funding. We thank all students and teachers who participated in this research.

\section{References}

[1] ATALIBA, P; MOURÃO, L. Evaluation of the impact of the Health Program in Schools. School and Educational Psychology. v. 22, n. 1. 2018. Available at: $<$ https://www.scielo.br/scielo.php?pid=S1413-

$85572018000100027 \&$ script $=$ sci abstract\&tlng=en $>$. Access on: 5 Mar. 2021.

[2] AVELLEIRA, R; BOTTINO, G. Syphilis: diagnosis, treatment and control. Brazilian Dermatology's Health. v. 81, n. 2. 2006. Available

at: $<$ https://www.scielo.br/scielo.php?script=sci_arttext\&pid=S03 65-05962006000200002>. Access on: 5 Mar. 2021.

[3] BARBOSA, K. et al. Factors associated with non-use of condoms and prevalence of HIV, viral hepatitis B and C and syphilis: a cross-sectional study in rural communities in Ouro Preto, Minas Gerais, between 2014 and 2016. Journal Epidemiology and Health Services. Brasilia, v. 28, ed. 2. 2019. Available from: $<$ https://www.scielo.br/scielo.php?pid=S22379622019000200318\&script=sci_arttext. $>$ Accessed: Feb. 10 2021.

[4] BRAZIL (BRAZIL) Health Surveillance Secretariat. Syphilis - Diagnostic Strategies in Brazil... Department of STDs, AIDS and Viral Hepatitis. Ministry of Health. 2010. Available at: $<$ https://bvsms.saude.gov.br/bvs/publicacoes/sifilis_estrategia _diagnostico_brasil.pdf $>$. Accessed Feb. 20. 2021.

[5] BRAZIL. Health Surveillance Secretariat. Routine Manual for Assistance to Adolescents Living with HIV/AIDS. Brasilia. Ministry of health. 2006. Available at: $<$ http://bvsms.saude.gov.br/bvs/publicacoes/10001021667.pdf $>$. Accessed Jan 16, 2021.

[6] BRAZIL. Health Surveillance Secretariat. Technical report on human papillomavirus (HPV) vaccine in primary care. Brasilia, 2014. Ministry of Health Available at: < https://portalarquivos2.saude.gov.br/images/pdf/2015/junho/2 6/Informe-T--cnico-Introdu----o-vacina-HPV-18-2-2014.pdf>. Accessed Jan 17, 2021.

[7] BRAZIL. Caring for Adolescents: basic guidelines for sexual and reproductive health. Ministry of Health. 2 ed. Brasilia, 2018. Available from: $<$ http://bvsms.saude.gov.br/bvs/publicações/cuidando_adolesc entes saude_sexual reprodutiva_2ed.pdf $>$. Accessed: 16 Jan 2021 .

[8] BRAZIL. Department of Health Surveillance Department of STD, AIDS and Viral Hepatitis Clinical Protocol and Therapeutic Guidelines (PCDT) Comprehensive Care for People with Sexually Transmitted Infections (STIs). 2020. Ministry of Health.2020. Available in: < https://portaldeboaspraticas.iff.fiocruz.br/wp-

content/uploads/2020/08/pcdt_ist_final_revisado_020420.pdf $>$ Accessed: 20 Feb. 2021

[9] CRUZ, Z. L. et al. Adolescents' knowledge about contraception and sexually transmitted infections. Revista Adolescência e Saúde. v. 15, n. 2., 2018. Available from: $<\mathrm{http}: / /$ www.adolescenciaesaude.com/detalhe artigo.asp?id=7 14>. Accessed: 22 Feb. 2021.

[10] MAROLA The SANCHEZ. C, CARDOSO, L. Formation of concepts in sexuality in adolescence and its influences. Psychology of Education. No. 33. 2011. Available at: $<$ http://pepsic.bvsalud.org/scielo.php?script=sci_arttext\&pid= S1414-69752011000200006>. Access on: 5 Mar. 2021.

[11] MUNIZ, N. et al. Importance of health education in 
adolescence: emphasis on the prevention of sexually transmitted infections. University Extension in Health Sciences in $\quad 2020 . \quad$ Available at: $<$ https://www.atenaeditora.com.br/post-artigo/31406>.

Accessed: 15 Feb. 2021

[12] RAMOS, S; ARAÚJO A. sexually transmitted infections: guidelines and importance of prevention of young people and adolescents. FUCAMP notebooks. v. 19, n. 37. 2020. Available at:

$<$ https://www.fucamp.edu.br/editora/index.php/cadernos/articl e/view/2048>. Access: 6 Mar. 2021.

[13] SILVA, T.M.; BARBOSA, B. J. P. Knowledge and vulnerability of adolescents in relation to sexually transmitted infections. The Brazilian Journal of Infectious Diseases. v.22. 2018. Available at:

$<$ https://www.sciencedirect.com/science/article/pii/S14138670 18307839?via\%3Dihub>. Accessed: 12 Feb, 2021

[14] SOUSA, A; MARIANO M. Perception of adolescents from a public school of the baturite massif about sexually infections. $2017 . \quad$ Available at: $<$ http://repositorio.unilab.edu.br:8080/jspui/bitstream/1234567 89/991/1/Article.pdf>. Access on: 5 Mar. 2021.

[15] SOUSA, C. et al. Adolescents: greater vulnerability to STIs/AIDS? Original article. .2017. Available from: $<$ http://www.coren-ce.org.br/wpcontent/uploads/2019/02/ADOLESCENTES-MAIORVULNERABILIDADE-\%C3\%80S-ISTAIDS.pdf $>$. Access: 1 Mar. 2021.

[16] SILVA, L; FERREIRA, T J. The role of the school and its social demands. Journal Scientific Projection and Teaching. v. 5, n. 2 , 2014. Available from: $<$ http://revista.faculdadeprojecao.edu.br/index.php/Projecao3/ article/view/415>. Accessed: 17 Jan. 2021.

[17] CARVALHO, O; PINTO, R.G; SANTOS, M. S. Knowledge about sexually transmitted infections by adolescent students from public schools. Journal adolescence and health. v. 15, n. 1. 2018. Available at: $<\mathrm{http}: / /$ www.adolescenciaesaude.com/detalhe artigo.asp?id=7 03>. Access: 15 Dec. 2020.

[18] WORLD HEALTH ORGANIZATION, Global health sector strategy on Sexually Transmitted Infections,2016-2021. Available from: $<$ https://www.who.int/reproductivehealth/publications/rtis/ghs s-stis/en/>. Accessed: 28 Feb. 2021. 